\title{
ANALISIS KUALITAS PELAYANAN PRAMUWISATA TERHADAP KEPUASAN WISATAWAN DI PT. BALI SUN TOURS
}

\author{
I GA. Gede Luhur Winata Putra \\ I Putu Sudana \\ Ni Putu Eka Mahadewi \\ Email : gedeluhur@yahoo.com \\ PS. S1 Industri Perjalanan Wisata \\ Fakultas Pariwisata UNUD
}

\begin{abstract}
ABSTRAK
Meningkatnya kebutuhan orang untuk berwisata jelas akan mempengaruhi usaha disektor pariwisata. Dalam sektor pariwisata, pramuwisata yang juga menjadi ujung tombak dari pencitraan perusahaan sangatlah penting peranannya. Tujuan dari penulisan ini untuk mengukur tingkat kepuasan wisatawan terhadap kualitas pelayanan pramuwisata serta menghubungkan antara kepentingan dan kinerja terhadap kualitas pelayanan yang diberikan pramuwista PT. Bali Sun Tours. Data penelitian ini diperoleh melalui observasi, wawancara, penyebaran kuesioner, dokumen dan studi kepustakaan.

Hasil menunjukkan bahwa tingkat kepentinagn dan tngkat kinerja terhadap kualitas pelayanan pramuwisata di PT. Bali Sun Tours memperoleh rata-rata $87,62 \%$ artinya bahwa wisatawan yang menggunakan jasa pramuwisata di PT. Bali Sun Tours memperoleh kualitas pelayanan yang Baik. Berdasarkan hasil penelitian yang dianalisis menggunakan analisis importance performance, pada kuadran A yang merupakan prioritas utama terdapat 1 indikator, pada kuadran B yang merupakan atribut yang perlu dipertahankan terdapat 9 indikator, pada kuadran $\mathrm{C}$ terdapat 6 indikator yang merupakan atribut dengan proritas terendah, pada kuadran $\mathrm{D}$ terdapat 1 indikator yang merupakan atribut dengan prioritas berlebihan dalam pelaksanaanya.
\end{abstract}

Kata Kunci : Kualitas Pelayanan, Pramuwisata, Biro Perjalanan Wisata.

\section{PENDAHULUAN}

Terkenalnya Bali di dunia saat ini tidak lepas dari keberadaan biro perjalan wisata. Wisatawan mancanegara yang datang ke Bali menggunakan jasa biro perjalan wisata karena lebih efisien dan juga memperoleh informasi lebih banyak tentang fasilitas-fasilitas yang diperlukan dalam perjalanan. Semakin banyak orang-orang atau wisatawan yang menggunakan jasa biro perjalanan wisata untuk mengurus perjalanannya maka jumlah biro perjalanan wisata pun terus bertambah. Sebagai perusahaan yang bergerak di bidang biro perjalanan wisata selalu mementingkan kualitas pelayanan yang diberikan kepada para pelanggannya. Kualitas menunjukan bahwa produk yang dikonsumsi wisatawan mampu memenuhi kebutuhan dan keinginan wisatawan.

Salah satu biro perjalanan yang baru berkembang di Bali adalah Bali Sun Tours. Biro perjalanan ini memiliki pangsa pasar wisatawan Australia, Cina dan jepang yang berlokasi di Jl. Dewi Tunjung Biru Br. Karang Dalem II, Bongkasa Pertiwi, Abiansemal, Badung. Perusahaan ini sudah berdiri sejak tahun 2013 tapi masih berupa travel online dan sejak 2015 baru menjadi travel resmi (PT).

Berdasarkan observasi yang telah dilakukan penurunan terjadi karena masih adanya keluhankeluhan yang terjadi diantaranya wisatawan merasa belum puas dengan pelayanan yang 
diberikan oleh pramuwisata PT. Bali Sun Tours. Sedangkan PT. Bali Sun Tours memiliki misi "memberikan layanan yang berkualitas dan berstandar tinggi berupa kemudahan, kenyamanan dan kecepatan dalam layanan tours dan travel kepada pelanggan agar mereka puas dan loyal kepada perusahaan". Sehingga pada penelitian ini penulis tertarik untuk mengetahui bagaimana kualitas pelayanan yang diberikan oleh pramuwisata yang belum sesuai dengan misi yang dibuat oleh PT.Bali Sun Tours.

\section{METODE PENELITIAN}

Variabel yang digunakan didalam penulisan ini adalah Variabel kepuasan dan variable kinerja. Jenis data yang digunakan dalam penelitian ini menggunakan dua jenis data yaitu kualitatif dan kuantitaif. Sumber data primer adalah data yang diperoleh langsung dari sumber pertama di lokasi penelitian, data ini dikumpulkan secara langsung dari lapangan, yang diperoleh dengan cara pengamatan, survei serta wawancara atau memberi daftar pertanyaan. Dalam penelitian ini meliputi pihak PT. Bali Sun Tours dan data hasil penyebaran kuisioner

Pada penelitian ini yang akan dijadikan sampel adalah wisatawan yang menggunakan PT. Bali Sun tours. Pegambilan sampel dilakukan untuk memberikan penilaian wisatawan terhadap kualitas pelayanan pramuwisata. Jumlah sampel dalam penelitian ini adalah 99 orang Wisatawan dengan menggunakan rumus Slovin (dalam Noor 2013)

Teknik analisis data yang dipergunakan dalam penelitian ini adalah analisis deskriftif kuantitatif yaitu merupakan teknik analisis yang dilakukan dengan mentabulasi data, memaparkan situasi, peristiwa atau keadaan dengan melakukan penghitungan menggunakan rumus. Dalam penelitian ini hasil kuesioner yang merupakan data kualitatif diangkakan melalui analisis tingkat kepentingan dan kinerja/kepuasan penumpang (informanceperformance analysis), data dianalisis dengan Skala Likert dan Diagram Kartesius.

\section{HASIL DAN PEMBAHASAN}

Berdasarkan data yang diperoleh di lapangan dari 99 responden kemudian di analisis menggunakan Skala Likert, dan Diagram
Kartesius dengan alat bantu program SPSS 17.00

Berdasarkan Skala Likert dapat dijabarkan sebagai berikut:

1. Bukti Langsung (Tangible)

a. Penampilan pramuwisata yang rapi dan meyakinkan. Dari hasil menggunakan rumus rata-rata tingkat kepentingan untuk penampilan pramuwisata yang rapi dan meyakinkanadalah sebesar 4,24 yang artinya tingkat kepentingan dari penampilan pramuwisata yang rapi dan meyakinkan sangat penting.

b. Perlengkapan yang disediakan oleh pramuwisata (seperti obatobatan,P3k,dan lain-lain). Dari hasil menggunakan rumus rata-rata tingkat kepentingan untuk perlengkapan yang disediakan oleh pramuwisata adalah sebesar 3,59 yang artinya tingkat kepentingan dari perlengkapan yang disediakan oleh pramuwisata (seperti obat-obatan, P3K, dan lain-lain) penting.

c. Kebersihan dan Kenyamanan Transportasi yang disediakan. Dari hasil menggunakan rumus rata-rata tingkat kepentingan untuk kebersihan dan kenyamanan trasnportasi yang disediakanadalah sebesar 3,60yang artinya tingkat kepentingan dari kebersihan dan kenyamanan trasnportasi yang disediakan penting.

2. Empati (Emphaty)

a. Pramuwisata mampu memahami kebutuhan dan keinginan masingmasing wisatawan. Dari hasil menggunakan rumus rata-rata tingkat kepentingan untuk pramuwisata mampu memahami kebutuhan dan keinginan masing-masing wisatawan sebesar 4,20 yang artinya tingkat kepentingan dari pramuwisata mampu memahami kebutuhan dan keinginan masingmasing wisatawan penting.

b. Pramuwisata mampu komunikasi yang baik dengaan wistawan (informasi yang diberikan oleh pramuwisata mudah dipahami). Dari hasil menggunakan rumus rata-rata tingkat kepentingan untuk pramuwisata mampu melakukan komunikasi yang baik dengan wistawan 
(informasi yang diberikan oleh pramuwisata mudah dipahami) adalah sebesar 3,52 yang artinya tingkat kepentingan dari pramuwisata mampu melakukan komunikasi yang baik dengan wistawan (informasi yang diberikan oleh pramuwisata mudah dipahami) penting.

c. Kemudahan wisatawan untuk menghubungi pramuwisata apabila dibutuhkan. Dari hasil menggunakan rumus rata-rata tingkat kepentingan untuk untuk kemudahan wisatawan untuk menghubungi pramuwisata apabila dibutuhkanadalah sebesar 3,90 yang artinya tingkat kepentingan dari untuk kemudahan wisatawan untuk menghubungi pramuwisata apabila dibutuhkan penting.

3. Daya Tanggap (Responsivness)

a. Pramuwisata tanggap melayani wisatawan. Dari hasil menggunakan rumus rata-rata tingkat kepentingan untuk pramuwisata tanggap melayani wisatawan adalah sebesar 4,23 yang artinya tingkat kepentingan dari pramuwisata tanggap melayani wisatawansangat penting.

b. Pramuwisata bersedia merespon dan mengatasi complain wisatawan. Dari hasil menggunakan rumus rata-rata tingkat kepentingan untuk pramuwisata bersedia merespon dan mengatasi komplain wisatawanadalah sebesar 3,88 yang artinya tingkat kepentingan dari pramuwisata bersedia merespon dan mengatasi komplain wisatawan.

c. Respon Pramuwisata terhadap kritik dan saran dari wisatawan.. Dari hasil menggunakan rumus rata-rata tingkat kepentingan untuk respon pramuwisata terhadap kritik dan saran dari wisatawan adalah sebesar 4,02 yang artinya tingkat kepentingan dari respon pramuwisata terhadap kritik dan saran dari wisatawan penting.

4. Kehandalan (Reliability)

a. Pramuwisata dapat diandalkan dalam mengatasi masalah-masalah yang timbul selama perjalanan wisata. Dari hasil menggunakan rumus rata-rata tingkat kepentingan untuk pramuwisata dapat diandalkan dalam mengatasi masalahmasalah yang timbul selama perjalanan wisata adalah sebesar 4,09 yang artinya tingkat kepentingan dari pramuwisata dapat diandalkan dalam mengatasi masalah-masalah yang timbul selama perjalanan wisatapenting.

b. Pramuwisata memberi pelayanan sesuai dengan janji yang ditawarkan. Dari hasil menggunakan rumus rata-rata tingkat kepentingan untuk pramuwisata memberi pelayanan sesuai dengan janji yang ditawarkanadalah sebesar 3,48 yang artinya tingkat kepentingan dari pramuwisata memberi pelayanan sesuai dengan janji yang ditawarkanpenting.

c. Pramuwisata cepat dalam melayani wisatawan. Dari hasil menggunakan rumus rata-rata tingkat kepentingan untuk pramuwisata cepat dalam melayani wisatawanadalah sebesar 3,98 yang artinya tingkat kepentingan dari pramuwisata cepat dalam melayani wisatawan penting.

d. Pramuwisata dapat memberikan informasi yang akurat. Dari hasil menggunakan rumus rata-rata tingkat kepentingan untuk pramuwisata dapat memberikan informasi yang akuratadalah sebesar 3,54 yang artinya tingkat kepentingan dari pramuwisata dapat memberikan informasi yang akurat penting.

5. Jaminan (Assurance)

a. Pramuwisata berkompeten (memahami dan mampumelakukan) dalam pekerjaan. Dari hasil menggunakan rumus rata-rata tingkat kepentingan untuk pramuwisata berkompeten (memahami dan mampumelakukan) dalam pekerjaan adalah sebesar 4,17 yang artinya tingkat kepentingan dari pramuwisata berkompeten (memahami dan mampumelakukan) dalam pekerjaan penting.

b. Pramuwisata dapat menciptakan rasa aman bagi wisatawan. Dari hasil menggunakan rumus rata-rata tingkat kepentingan untuk pramuwisata dapat menciptakan rasa aman bagi 
wisatawanadalah sebesar 3,85 yang artinya tingkat kepentingan dari pramuwisata dapat menciptakan rasa aman bagi wisatawanpenting.

c. Keramahan, perhatian dan kesopanan pramuwisata dalam memberikan pelayanan kepada wisatawan. Dari hasil menggunakan rumus rata-rata tingkat kepentingan untuk keramahan, perhatian dan kesopanan pramuwisata dalam memberikan pelayanan kepada wisatawanadalah sebesar 3,88 yang artinya tingkat kepentingan dari keramahan, perhatian dan kesopanan pramuwisata dalam memberikan pelayanan kepada wisatawan penting.

d. Pramuwisata memiliki pengetahuan dalam keahlian atas produk dan jasa secara cepat. Dari hasil menggunakan rumus rata-rata tingkat kepentingan untuk pramuwisata memiliki pengetahuan dalam keahlian atas produk dan jasa secara cepatadalah sebesar 3,61 yang artinya tingkat kepentingan pramuwisata memiliki pengetahuan dalam keahlian atas produk dan jasa secara cepat penting.

e. Pramuwisata jujur dan dapat dipercaya. Dari hasil menggunakan rumus rata-rata tingkat kepentingan untuk pramuwisata jujur dan dapat dipercayaadalah sebesar 3,88 yang artinya tingkat kepentingan dari pramuwisata jujur dan dapat dipercayapenting.

\section{Diagram Kartesius}

Untuk menganalisis apakah semua karakteristik dari indikator kualitas pelayanan yang penting sudah dilakukan oleh pramuwisata PT. Bali Sun Tours maka digunakan importance performance analysis, sehingga berdasarkan perhitungan yang sebelumnya sudah dipaparkan, nilai perhitungan tersebut akan digunakan dalam menentukan dua buah garis $\mathrm{X}$ dan $\mathrm{Y}$ yang berpotongan tegak lurus yang membagi diagram kartesius menjadi empat bagian. Selanjutnya indikator dari tingkat kinerja dan kepentingan akan dimasukan dalam diagram kartesius. Terlihat bahwa indikator yang mempengaruhi kepuasan wisatawan terhadap kualitas pelayanan pramuwisata PT. Bali Sun Tours terbagi menjadi empat bagian, adapun penjelasan masing-masing dari kuadran tersebut adalah sebagai berikut :

1. Kuadran A (Prioritas Utama). Menunjukan bahwan indikator-indikator yang mempengaruhi tinkat kepuasan wisatawan terhadap kualitas pelayanan pada jasa pramuwisata PT. Bali Sun Tours yang penanganannya perlu di prioritaskan adalah:

a. Pramuwisata jujur dan dapat dipercaya

2. Kuadran B (Prioritas Prestasi). Menunjukan bahwan indikator-indikator yang mempengaruhi tinkat kepuasan wisatawan terhadap kualitas pelayanan pada jasa pramuwisata PT. Bali Sun Tours yang penanganannya perlu dipertahankan adalah :

a. Penampilan pramuwisata yang rapi dan meyakinkan

b. Pramuwisata mampu memahami kebutuhan dan keinginan masingmasing wisatawan

c. Pramuwisata tanggap melayani wisatawan

d. Pramuwisata berkompeten (memahami dan mampumelakukan) dalam pekerjaan

e. Pramuwisata dapat diandalkan dalam mengatasi masalah-masalah yang timbul selama perjalanan wisata

f. Respon pramuwisata terhadap kritik dan saran dari wisatawan

g. Pramuwisata cepat dalam melayani wisatawan

h. Kemudahan wisatawan untuk menghubungi pramuwisata apabila dibutuhkan

i. kesopanan pramuwisata dalam memberikan pelayanan kepada wisatawan

3. Kuadran C (Prioritas Rendah). Menunjukan bahwan indikator-indikator yang mempengaruhi tinkat kepuasan wisatawan terhadap kualitas pelayanan pada jasa pramuwisata PT. Bali Sun Tours dinilai kurang penting bagi wisatawan dan dalam pelaksanaanya biasa atau cukup baik adalah:

a. Pramuwisata memiliki pengetahuan dalam keahlian atas produk dan jasa secara cepat

b. Perlengkapan yang disediakan oleh pramuwisata (seperti obat-obatan, P3K, dan lain-lain) 
c. Kebersihan dan kenyamanan trasnportasi yang disediakan

d. Pramuwisata dapat memberikan informasi yang akurat

e. Pramuwisata mampu melakukan komunikasi yang baik dengaan baik dengan wistawan (informasi yang diberikan oleh pramuwisata mudah dipahami)

f. Pramuwisata memberi pelayanan sesuai dengan janji yang ditawarkan

4. Kuadran D (Berlebihan). Menunjukan bahwan indikator-indikator yang mempengaruhi tinkat kepuasan wisatawan terhadap kualitas pelayanan pada jasa pramuwisata PT. Bali Sun Tours dinilai sangat memuaskan sehingga wisatawan menganggap ini berlebihan adalah Pramuwisata dapat menciptakan rasa aman bagi wisatawan

Berdasarkan indikator yang mendapatkan prioritas utama dalam melakukan pelayanan terhadap wisatawan yang menggunakan jasa pramuwisata PT. Bali Sun Tours adalah kebersihan dan kenyamanan trasnportasi yang disediakan dengan tingkat kesesuaian 81,79 persen, pramuwisata memiliki pengetahuan dalam keahlian atas produk dan jasa secara cepat dengan tingkat kesesuaian 86,87 persen (prioritas kedua), pramuwisata dapat memberikan informasi yang akurat dengan tingkat kesesuaian 87,46 persen (prioritas ketiga), pramuwisata berkompeten (memahami dan mampumelakukan) dalam pekerjaan dengan tingkat kesesuaian 88,37 persen (prioritas keempat).

Pramuwisata memberi pelayanan sesuai dengan janji yang ditawarkan dengan derajat kepentingan 88,40 persen (prioritas kelima), Pramuwisata cepat dalam melayani wisatawan dengan tingkat kesesuaian 88,60 persen (prioritas keenam), Pramuwisata mampu memahami kebutuhan dan keinginan masingmasing wisatawan dengan tingkat kesesuaian 89,90 persen (prioritas ketujuh), Pramuwisata tanggap melayani wisatawan dengan tingkat kesesuaian 89,97 (prioritas kedelapan), Pramuwisata jujur dan dapat dipercaya dengan tingkat kesesuaian 90,30 persen (prioritas kesembilan), Pramuwisata dapat diandalkan dalam mengatasi masalah-masalah yang timbul selama perjalanan wisata dengan tingkat kesesuaian 90,61 persen (prioritas kesepuluh).

Kemudahan wisatawan untuk menghubungi pramuwisata apabila dibutuhkan dengan tingkat kesesuaian 90,69 persen (prioritas kesebelas), Perlengkapan yang disediakan oleh pramuwisata (seperti obatobatan, P3K, dan lain-lain) dengan tingkat kesesuaian 91,85 (prioritas keduabelas), Respon pramuwisata terhadap kritik dan saran dari wisatawan dengan tingkat kesesuaian 92,21 persen (prioritas ketigabelas), Pramuwisata mampu melakukan komunikasi yang baik dengaan baik dengan wistawan (informasi yang diberikan oleh pramuwisata mudah dipahami) dengan tingkat kesesuaian 93,12 persen (prioritas keempatbelas), Keramahan, perhatian dan kesopanan pramuwisata dalam memberikan pelayanan kepada wisatawan dengan tingkat kesesuaian 93,76 persen (prioritas kelimabelas).

Penampilan pramuwisata yang rapi dan meyakinkan dengan tingkat kesesuaian 94,52 persen (prioritas keenambelas), Pramuwisata dapat menciptakan rasa aman bagi wisatawan dengan tingkat kesesuaian 97,12 persen (prioritas ketujuhbelas) dan prioritas kedelapanbelas atau prioritas terakhir dari semua indikator penelitian adalah Pramuwisata bersedia merespon dan mengatasi komplain wisatawan dengan tingkat kesesuaian 97,66 persen.

\section{SIMPULAN DAN SARAN Simpulan}

Berdasarkan hasil dari kualitas pelayanan pramuwisata di PT. Bali Sun Tours, maka dapat disimpulkan bahwa tingkat kepuasan wisatawan terhadap pelayanan pramuwisata di PT. Bali Sun Tours, dengan menggunakan teknik analisis data tingkat kepentingan dan kinerja atau Importance Performance Analysis, dari responden sebanyak 99 orang wisatawan bahwa dari hasil perhitungan seluruh indikator tingkat kepuasan memperoleh rata-rata kepentingan sebesar 3,51 dan memperoleh katagori baik.

Perhitungan tingkat kinerja dari seluruh indikator memperoleh rata-rata sebesar 3,88 dan memperoleh kategori baik. Perhitungan dari keseluruh indikator untuk tingkat kesesuaian mendapatkan rata-rata sebesar 87,62 persen, 
yang artinya wisatawan merasa puas dengan pelayanan jasa yang diberikan oleh pramuwisata dari PT. Bali Sun Tours.

Perhitungan dari diagram kartesius memperoleh bahwa kuadran A terdiri dari satu indikator yang memperoleh prioritas utama dari kualitas pelayanan yang diberikan kepada wisatawan, dari kuadran B terdapat sembilan indikator yang harus dipertahankan atau ditingkatkan karena telah mampu memenuhi harapan wisatawan, dari kuadran $\mathrm{C}$ terdapat enam indikator didalamnya karena merupakan kualitas terendah dari kualitas pelayanan yang dinerikan kepada wisatawan dan kuadran D terdiri dari satu indikator yang merupakan pelayanan yang terlalu berlebihan dalam memberikan pelayanan kepada wisatawan.

\section{Saran}

Adapun saran yang dapat dikemukakan bagi pihak pramuwisata di PT. Bali Sun Tours diantaranya sebagai berikut:

1. Diharapkan bagi pramuwisata di PT. Bali Sun Tours agar meningkatkan kebersihan tranportasi yang digunakan dalam melakukan perjalanan wisata, agar wisatawan nyaman dalam melakukan perjalanan wiasata.

2. Pramuwisata hendaknya pengetahuan dan bahasa yang fasih sehingga produk yang akan diberikan wisatawan mampu dipahami wisatawan, sehingga wisatawan tidak bingung dalam melakukan perjalanan wisata.

\section{DAFTAR PUSTAKA}

Any Noor, 2013, Manajemen Event, Bandung : Alfabeta.

Kusmayadi dan Sugiarto, Endar. 2000. Metodologi Penelitian Dalam Bidang Kepariwisataan. Jakarta : PT. Gramedia Pustaka Utama.

Mancini AJ, 2001. Conducting Tours. Third edition. USA : Delmar.

Parasuraman, A, Valarile A. Zeithaml, dan Leonard L, Berry, 1985. A Conceptual Model of Service Qalitu and Its Implication for Future Research,Journal of Marketing Volume 49 (Fall). 